\title{
Donato Sperduto, Les farces nocturnes: Balzac et Patrick Modiano
}

\section{Marco Stupazzoni}

\section{(2) OpenEdition Journals}

Edizione digitale

URL: http://journals.openedition.org/studifrancesi/8664

DOI: $10.4000 /$ studifrancesi.8664

ISSN: 2421-5856

\section{Editore \\ Rosenberg \& Sellier}

\section{Edizione cartacea}

Data di pubblicazione: 1 décembre 2008

Paginazione: 687

ISSN: 0039-2944

\section{Notizia bibliografica digitale}

Marco Stupazzoni, «Donato Sperduto, Les farces nocturnes: Balzac et Patrick Modiano», Studi Francesi [Online], 156 (LII | III) | 2008, online dal 30 novembre 2015, consultato il 08 janvier 2021. URL: http:// journals.openedition.org/studifrancesi/8664 ; DOI: https://doi.org/10.4000/studifrancesi.8664

Questo documento è stato generato automaticamente il 8 janvier 2021.

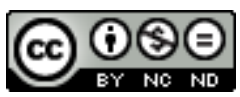

Studi Francesi è distribuita con Licenza Creative Commons Attribuzione - Non commerciale - Non opere derivate 4.0 Internazionale. 


\title{
Donato Sperduto, Les farces nocturnes: Balzac et Patrick Modiano
}

\author{
Marco Stupazzoni
}

NOTIZIA

DONATO SPERDUTO, Les farces nocturnes: Balzac et Patrick Modiano, in «Lendemains», $\mathrm{n}^{\circ}$ 114-115, 2004, pp. 226-236.

In questo studio, D. Sperduto stabilisce interessanti analogie tra la descrizione delle imprese dovute ai Chevaliers de la Désoeuvrance ne La Rabouilleuse di Balzac e quelle proprie dei Chevaliers de l'ombre ne La Ronde de nuit di P. Modiano. L'autore si propone, in particolare, di «élucider la façon tantôt comique, tantôt dramatique dans laquelle les deux écrivains ont représenté des victimes de l'Histoire» (p. 226). 